BIOEDUSCIENCE

Jurnal Pendidikan Biologi dan Biosain

DOI: $\underline{10.29405 / \text { bioeduscience/24-30111179 }}$

\title{
Keanekaragaman dan Pola Penyebaran Insekta Permukaan Tanah di Resort Cisarua Taman Nasional Gunung Gede Pangrango Jawa Barat
}

\author{
Dwi Meilina Andrianni ${ }^{1}$, Maryanti Setyaningsih ${ }^{1}$, Susilo $^{1 *}$, Meitiyani $^{1}$, Agus Pambudi Darma ${ }^{1}$ \\ ${ }^{1}$ Pendidikan Biologi, Universitas Muhammadiyah Prof. DR. HAMKA, Pasar, Rebo, Jakarta Timur, Indonesia \\ *Email korespondensi: susilo@uhamka.ac.id
}

Received: 27 Oktober 2017 | Accepted: 25 November 2017 | Published: 25 Desember 2017

\section{ABSTRAK}

Penelitian ini bertujuan untuk mengetahui keanekaragaman dan pola penyebaran insekta permukaan tanah di Taman Nasional Gunung Gede Pangrango (TNGGP). Penelitian ini dilakukan di Resort Cisarua TNGGP Jawa Barat, dilaksanakan pada bulan Februari-Maret 2015. Teknik sampling yang digunakan adalah Pit Fall Trap dari transek garis. Analisis data menggunakan pengukuran Kelimpahan Relatif (KR), Indeks Kekayaan Spesies (R), Indeks Keanekaragaman Shannon-Weaver (H'), Indeks Kemerataan Spesies (E), dan Indeks Dominansi Simpson (C), Indeks Kesamaan Sorensen (Cs) dan Indeks Morista (I). Hasil penelitian menunjukkan ordo yang ditemukan dari keempat lokasi diantaranya ordo Coleoptera, Orthoptera, Hymenoptera, Isoptera, Dermaptera Dan Diptera. Keanekaragaman insekta tertinggi dari keempat lokasi berada di daerah hutan primer dengan nilai $\mathrm{H}^{\prime}=2.20, \mathrm{E}=0.95, \mathrm{C}=0.12 \mathrm{R}=3.62$, dan memiliki dominansi terendah yaitu $\mathrm{C}=0.12$. Sedangkan keanekaragaman insekta terendah berada di daerah ladang pertanian $\mathrm{H}^{\prime}=1.50, \mathrm{E}=0.65, \mathrm{R}=2.14$, dan memiliki dominansi yang tinggi yaitu $\mathrm{C}=0.31$. Pola penyebaran yang terjadi antara keempat lokasi diantaranya ladang pertanian, hutan sekunder, tepian sungai, dan hutan primer dari masing-masing plot memiliki pola penyebaran yang berkelompok.

Kata kunci: keanekaragaman; pola sebaram; insekta; serangga tanah; taman nasional

Copyright $(\mathcal{C} 2017$ BIOEDUSCIENCE All rights reserved

\section{PENDAHULUAN}

Taman Nasional Gunung Gede Pangrango adalah kawasan hutan hujan tropis yang berada di daerah provinsi Jawa Barat pada lintang $106^{\circ} 51^{\prime}-107^{\circ} 02^{\prime}$ BT dan $64^{\circ} 1^{\prime}-65^{\circ} 1^{\prime}$ LS dengan ketinggian puncak gunung mencapai $2.958 \mathrm{mdpl}$ (meter diatas permukaan laut). Hutan hujan tropis berfungsi sebagai tempat hidupnya berbagai macam flora dan fauna di alam. Bentuk tanah yang terdapat di TNGGP memiliki tingkat kesuburan yang tinggi.

Menurut Indriyanto (2006), tanah merupakan bagian dari alam (bumi) yang berasal dari berbagai hasil pelapukan dari iklim dan terdiri atas komposisi bahan organik dan anorganik yang terdapat pada keseluruhan bumi, sehingga dapat memberikan air, udara, dan hara bagi tumbuhan, serta berfungsi sebagai tempat berdiri tegaknya tumbuhan. Namun, menurut Poth (1992) tanah adalah tempat hidupnya berbagai tanaman, binatang, dan kehidupan mikroba. Banyak hewan yang hidup di dalam tanah maupun permukaan tanah, dari beberapa hewan tersebut adalah filum Arthropoda. Dari filum arthropoda yang terdapat di dalam tanah maupun permukaan tanah yang paling dominan jumlahnya yaitu kelas insekta. Sehingga insekta dimasukkan

kedalam kelompok kelas yang lebih besar dalam Filum Arthropoda.

Menurut Borror et al. (1992), menyatakan bahwa tanah bagi serangga 
berfungsi sebagai pemukiman atau sarang, pertahanan, dan makanan. Kehidupan serangga di tanah sangat dipengaruhi oleh faktor lingkungan. Ada dua macam yang berperan dalam kelangsungan faktor lingkungan yaitu lingkungan fisik dan kimia. Lingkungan fisik terdiri dari warna tanah, suhu tanah, konsistensi tanah, tekstur tanah, kerapatan tanah, dan kandungan air tanah. Lingkungan kimia meliputi $\mathrm{pH}$ tanah, kadar organik tanah, nitrogen tanah, kerapatan tanah, dan nilai tukar kation tanah (Suin, 2006).

Peranan insekta dalam kehidupan antara lain yaitu sebagai pemakan zat organik yang telah membusuk sehingga insekta dapat membantu memisahkan zatzat yang berbahaya bagi lingkungan, sebagai makanan bagi hewan-hewan lain (seperti jenis ikan, unggas, dan mamalia), dan dalam bidang kedokteran larva lalat hijau sebagai obat bagi jaringan yang membusuk. Sehingga dalam mengidentifikasi keanekaragaman dan pola penyebaran di permukaan tanah sangat penting dalam mengetahui keterkaitannya peranan serangga di kawasan resort Taman Nasional Gunung Gede Pangrango.

Serangga dapat ditemukan hampir pada setiap habitat terrestrial seperti tanah, air tawar, dan serangga terbang mengisi udara (Campbell et al., 2003). Lingkungan tanah adalah lingkungan yang terdiri atas lingkungan biotik dan lingkungan abiotik. Gabungan dari kedua lingkungan tersebut menghasilkan suatu daerah yang dijadikan tempat pemukiman bagi beberapa jenis makhluk hidup, salah satu diantaranya adalah serangga tanah.

Faktor lingkungan tersebut akan mempengaruhi adanya keanekaragaman dan pola penyebaran serangga permukaan tanah. Faktor biotik dan faktor abiotik dalam suatu ekosistem menentukan adanya kelimpahan, keberadaan serangga tanah, dan munculnya suatu organisme. Parameter dalam ekosistem diukur untuk mengetahui adanya nilai keanekaragaman spesies.
Kenanekaragaman menurut Pielou (1975) adalah suatu jumlah spesies yang sudah ada pada suatu waktu dalam komunitas tertentu (Suheriyanto 2008).

Keanekaragaman spesies dikatakan tinggi apabila suatu komunitas memiliki kompleksitas tinggi, hal ini dikarenakan adanya interaksi spesies yang terjadi didalam suatu komunitas itu sangat tinggi dan disusun oleh banyaknya spesies. Sebaliknya, komunitas dikatakan mempunyai keanekaragaman spesies rendah pada suatu komunitas terjadi jika komunitas tersebut disusun oleh spesies dalam jumlah sedikit dan jika hanya ada sedikit spesies yang dominan (Indriyanto, 2006).

Pola-pola penyebaran dapat dipengaruhi oleh derajat sosialisasi dalam sebuah populasi, interaksi dengan spesies lain, ketersediaan sumber daya, dan lain sebagainya. faktor dispersive dominan menyebarkan anggota-anggota suatu populasi.

\section{MATERI DAN METODE}

Penelitian ini bersifat deskriptif analitik. metode penelitian yang digunakan adalah transek garis dengan menggunakan teknik sampling. Teknik sampling penelitian ini menggunakan teknik Pit Fall Trap.

Penelitian di lapangan menggunakan alat dan bahan sebagai berikut: ATK, label kertas, kuas lukis, gelas plastik, mika cover (merah, kuning, dan hijau), Styrofoam, plastik obat berukuran sedang, kawat, sekop tanah, GPS, lux meter, hygrometer, $\mathrm{pH}$ meter, alkohol 96\%, dan air detergen dengan perbandingan 1: 100. Untuk penelitian di laboratorium menggunakan alat dan bahan, yaitu:

ATK, Microcam, Mikroskop, pinset, cawan petri, label kertas, kuas lukis, tisu, dan alkohol 96\%.

Lokasi pengambilan sampel penelitian empat titik lokasi pengamatan antara lain: 1) Ladang pertanian, 2) Hutan 
sekunder, 3) Tepian sungai, dan 4) Hutan primer. Pengumpulan data dilakukan menggunakan metode perangkap jebakan (pit fall trap), pit fall trap ini pada masingmasing titik lokasi diletakkan selama 24 jam. Pit fall trap adalah jebakan atau perangkap yang digunakan untuk Pengumpulan serangga permukaan tanah dengan memasang perangkap jebakan tergolong pada pengumpulan hewan secara dinamik (Suin, 2006).

Pengambilan sampel dilakukan dengan cara memasang 10 pitfall pada setiap satu lokasi jalur pendakian. Perangkap jebak dibuat oleh gelas plastik yang di tanam di permukaan tanah. Permukaan gelas plastik dibuat datar sejajar dengan tanah. Mika cover dan styrofoam yang telah ditempelkan di beri penyangga berupa kawat, dan agar air yang mengalir di permukaan tanah tidak masuk ke dalam perangkap maka perangkap dipasang pada tanah yang datar dan sedikit agak tinggi. Jarak antar perangkap yaitu $5 \mathrm{~cm}$.

Perangkap diisi dengan alkohol 96\% dan air detergen. Perangkat jebakan dengan umpan alkohol $96 \%$ dan air detergen digunakan agar insekta yang terperangkap adalah insekta yang tertarik oleh bau umpan yang diletakkan di dalam gelas plastik perangkap. Insekta yang jatuh ke dalam perangkap akan terawet oleh alkhol dan detergen yang diletakkan dalam perangkap.

Pengambilan data faktor lingkungan dilakukan pada siang hari. Pengambilan data dilakukan bersamaan dengan pengambilan sampel. Data yang diambil meliputi ketinggian ordinat, suhu udara, suhu tanah, kelembaban tanah, kelembaban udara, pH tanah, cahaya, dan lapisan serasah pada tiga titik didalam masingmasing lokasi pengamatan.

Sampel yang didapat kemudian dibawa ke Laboratorium Biologi Universitas Muhammadiyah Prof. DR. Hamka Jakarta untuk diidentifikasi dengan menggunakan buku terjemahan identifikasi An Introduction to the Study of Insect (Gadjah Mada Universitas Press, 1992) dan verifikasi di laboratorium entomologi, LIPI Cibinong.

Menurut Suheriyanto (2008), keanekaragaman lebih mudah bila digambarkan dengan menggunakan indeks keanekaragaman yang umum digunakan, yaitu indeks keanekaragaman ShannonWeiner $\left(\mathrm{H}^{\prime}\right)$. Selain menggunakan indeks keanekaragaman Shannon-Weiner perhitungan keanekaragaman spesies juga menggunakan perhitungan kekayaan spesies, kesamaan komunitas sorensen, kelimpahan relatif, dominansi dan kemerataan spesies untuk mendapatkan banyaknya keanekaragaman spesies di lokasi penelitian.

Pola penyebaran pada hewan tanah di suatu daerah bergantung pada keadaan faktor fisik-kimia lingkungan dan sifat biologis hewan tersebut. Rumus perhitungan pola penyebaran menggunakan indeks morista (I) (Suin, 1997).

\section{HASIL}

Pengamatan insekta permukaan tanah yang ditemukan dari keempat lokasi terdiri dari 6 ordo, 18 famili, dan 199 individu yaitu ordo Coleoptera, Orthoptera, Hymenoptera, Isoptera, Dermaptera dan Diptera. Sedangkan famili yang ditemukan diantaranya adalah Hydrophilidae, Scarabaeidae, Chrysomelidae, Ptiliidae, Staphylinidae, Eucinetidae, Carabidae, Muscidae, Drosophilla, Mycetophilidae, Sphaeroceridae, Cecidomyiidae, Dolichopodidae, Formicidae, Gryllidae, Rhinotermitidae, Anisolabididae, dan Carcinophoridae.

\section{Indeks kelimpahan relatif (KR)}

Hasil pengamatan menunjukkan bahwa kelimpahan insekta permukaan tanah banyak di temukan di daerah tepian sungai yaitu 69 individu dan terendah pada daerah hutan primer yaitu 12 individu. Sehingga mendapatkan kelimpahan relatif (Gambar 4). 


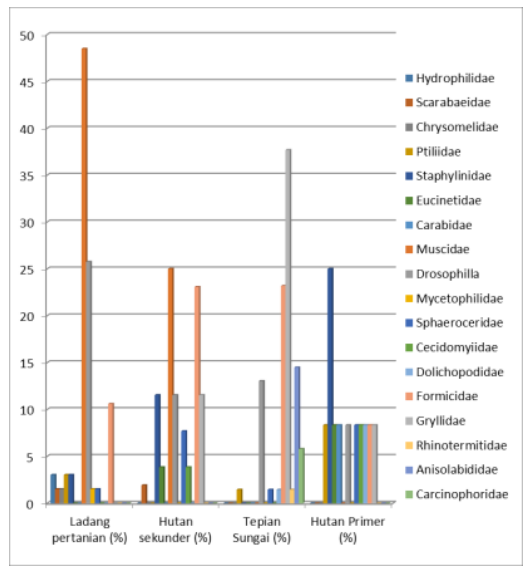

Gambar 1. Kelimpahan famili insekta permukaan tanah di keempat lokasi penelitian

\section{Indeks kesamaan sorensen (Cs)}

Indeks kesamaan komunitas antara daerah ladang pertanian, hutan sekunder, tepian sungai, dan hutan primer pada tabel 2. Nilai yang didapatkan yaitu $0.14-0.50$.

Hasil tersebut menunjukkan nilai tersebut mendekati nilai 0 yang berarti kesamaan komunitas dari keempat lokasi pengamatan tergolong rendah.

Tabel 1. Nilai indeks kesamaan famili di keempat lokasi pengamatan

\begin{tabular}{ccccc}
\hline Lokasi & $\begin{array}{c}\text { Ladang } \\
\text { pertanian }\end{array}$ & $\begin{array}{c}\text { Hutan } \\
\text { sekunder }\end{array}$ & $\begin{array}{c}\text { Tepian } \\
\text { sungai }\end{array}$ & $\begin{array}{c}\text { Hutan } \\
\text { primer }\end{array}$ \\
\hline Ladang pertanian & 1 & & & \\
Hutan sekunder & 0.50 & 1 & & \\
Tepian sungai & 0.27 & 0.41 & 1 & \\
Hutan primer & 0.15 & 0.28 & 0.14 & 1 \\
\hline
\end{tabular}

3. Indeks kekayaan spesies (R), spesies, dan kemerataan spesies dari keanekaragaman spesies (H'), keempat lokasi (Tabel 3). Dari hasil tabel kemerataan spesies (E), dominansi (C) menunjukkan bahwa nilai indeks kekayaan spesies, indeks keanekaragaman spesies, Hasil perbandingan nilai indeks dan kemerataan spesies tertinggi terdapat kekayaan spesies, indeks keanekaragaman pada daerah hutan primer

Tabel 2. Nilai indeks kekayaan spesies (R), keanekaragaman spesies (H'), indeks kemerataan spesies (E) dan dominansi (C)

\begin{tabular}{ccccc}
\hline Indeks & $\begin{array}{c}\text { Ladang } \\
\text { Pertanian }\end{array}$ & $\begin{array}{c}\text { Hutan } \\
\text { Sekunder }\end{array}$ & $\begin{array}{c}\text { Tepian } \\
\text { Sungai }\end{array}$ & $\begin{array}{c}\text { Hutan } \\
\text { primer }\end{array}$ \\
\hline Kekayaan Spesies (R) & 2.14 & 2.02 & 1.88 & 3.62 \\
Keanekaragaman Spesies (H') & 1.5 & 1.93 & 1.65 & 2.2 \\
Kemerataan Spesies (E) & 0.65 & 0.87 & 0.75 & 0.95 \\
Dominansi (C) & 0.31 & 0.16 & 0.23 & 0.12 \\
\hline
\end{tabular}




\section{Pola penyebaran}

Tingkat pola penyebaran dari keempat lokasi yaitu ladang pertanian, hutan sekunder, tepian sungai, dan hutan primer dari masing-masing plot per lokasi adalah pola penyebaran berkelompok. Hal ini ditunjukkan dengan perhitungan indeks morista yang dihasilkan yaitu bernilai 10, yang berarti distribusi yang terjadi pada serangga permukaan tanah di keempat lokasi itu berkelompok.

\section{PEMBAHASAN}

Komposisi suatu insekta permukaan tanah dipengaruhi oleh jumlah individu yang didapatkan di lokasi pengamatan. Ordo yang dominan ditemukan dari keempat lokasi adalah Ordo Coleoptera, Orthoptera, Hymenoptera, Isoptera, Dermaptera dan Diptera, hal ini disebabkan karena beberapa serangga beraktivitas di permukaan tanah (Borror et al.,1992). Selain itu keenam ordo tersebut berfugsi dalam merubah zat-zat bahan organik menjadi zat yang lebih sederhana yang dikembalikan ke tanah, dan serangga yang masuk kedalam ordo ini juga bertindak menyingkirkan zat-zat yang berbahaya dari lingkungan (Borror et al. 1992).

Berdasarkan hasil penelitian menunjukkan bahwa Ordo Diptera (famili Muscidae dan Drosophilla) dan Ordo Hymenoptera (famili Formicidae) memiliki kelimpahan yang tertinggi dari keempat lokasi penelitian yaitu ladang pertanian, hutan sekunder, tepian sungai, dan hutan primer.

Formicidae memiliki kelimpahan 17 individu di ladang pertanian, 6 individu di hutan sekunder, 9 individu di tepian sungai, dan 1 individu di hutan primer. Formicidae merupakan serangga yang menggunakan tanah sebagai tempat habitat utamanya yaitu berupa pemukiman dan sebagai tempat perlindungan. Muscidae dan Drosophilla kedua famili ini adalah famili yang paling banyak ditemukan di keempat lokasi penelitian.
Muscidae memiliki 32 individu di ladang pertanian dan 13 individu di hutan sekunder, namun pada kedua lokasi yang lain tidak di temukan Famili Muscidae. Sedagkan Drosophilla yang ditemukan memiliki 17 individu di ladang pertanian, 6 individu di hutan sekunder, 9 individu di tepian sungai, dan 1 individu di hutan primer. Kemungkinan dari kedua Famili ini merupakan serangga yang pemakan zat organik yang membusuk, maka beberapa serangga ini banyak ditemukan di keempat lokasi ini. Karena di keempat lokasi ini terdapat serasah daun yang merupakan zat organik yang membusuk dari tanaman di sekitar daerah umpan jebakan.

Jumlah individu yang di temukan dari keempat lokasi penelitian yaitu ladang pertanian, hutan sekunder, tepian sungai, dan hutan sekunder mencakup 6 Ordo, 18 Famili, 199 individu.

Muscidae pada ladang pertanian dan hutan sekunder relatif sangat tinggi yaitu 48 $\%$ dan 25\% dibandingkan dengan kedua lokasi lainnya. Kelimpahan relatif Formicidae pada ladang pertanian, hutan sekunder, tepian sungai, dan hutan primer relatif sama persentase kelimpahannya yaitu $10.6 \%, 23 \%$, 23\%, dan 8.3\%. Sehingga mempengaruhi kelimpahan relatif sama dari famili Formicidae tersebut.

Kelimpahan Drosophilla juga tidak berbeda jauh dianatara keempat lokasi penelitian yaitu pada ladang pertanian $25.75 \%$, hutan sekunder $11.5 \%$, tepian sungai $13 \%$, dan hutan primer $8.3 \%$. Dari keseluruhan famili yang ditemukan di keempat lokasi penelitian tersebut yang memiliki kelimpahan relatif yang tinggi Muscidae, Formicidae, dan Drosophilla.

Berdasarkan tingkat kesamaan komunitas antar keempat daerah rendah berkisar antara 0.14-0.50 (Tabel 2), maka indeks kesamaan komunitasnya mendekati nol yang berarti indeks kesamaan komunitasnya mempunyai komposisi spesies yang berbeda. Hal ini dikarenakan kondisi lingkungan di antara lokasi 
berbeda-beda dan hanya jenis tertentu saja yang dapat menyesuaikan diri dengan kondisi lingkungannya. Indeks kesamaan pada ladang pertanian dan hutan sekunder yaitu sebesar 0,50 dan hanya memiliki 50\% jenis yang sama. Kesamaan jenis pada ladang pertanian dan tepian sungai sebesar 0.27 dan ladang pertanian dan hutan primer sebesar 0.15 . sehingga memiliki $27 \%$ dan $15 \%$ jenis yang sama. Indeks kesamaan pada hutan sekunder dan tepian sungai sebesar 0.41, hutan sekunder dan hutan primer sebesar 0.28 maka memiliki $41 \%$ dan $28 \%$ jenis yang sama. Sedangkan pada tepian sungai dan hutan primer sebesar 0.14 dan haya memiliki $14 \%$ jenis yang sama.

Keanekaragaman spesies, kekayaan serangga, dan kemerataan spesies yang berada di permukaan tanah pada lokasi hutan primer lebih tinggi di hitung dengan menggunakan indeks keanekaragaman Shannon, kemerataan spesies, dominansi dan kekayaan spesies, yaitu $\mathrm{H}^{\prime}=1.50-2.20$, $\mathrm{E}=0.65-0.95, \mathrm{C}=0.12-0.31$ dan $\mathrm{R}=1.88$ 3.62 (Tabel 3).

Keanekaragaman insekta tertinggi dari keempat lokasi berada di daerah hutan primer dengan nilai $\mathrm{H}^{\prime}=2.20, \mathrm{E}=0.95, \mathrm{C}=$ $0.12 \mathrm{R}=3.62$, dan memiliki dominansi terendah yaitu $\mathrm{C}=0.12$. Sedangkan keanekaragaman insekta terendah berada di daerah ladang pertanian $\mathrm{H}^{\prime}=1.50, \mathrm{E}=0.65$, $\mathrm{R}=2.14$, dan memiliki dominansi yang tinggi yaitu $\mathrm{C}=0.31$. keanekaragaman insekta dari keempat lokasi tergolong keanekaragaman jenis yang sedang, hal ini dikarenakan keanekaragaman spesies ( $\left.\mathrm{H}^{\prime}\right)$ di keempat lokasi penelitian berkisar antara 1.50 sampai 2.20, yang berarti dalam keempat lokasi jumlah spesies dan individunya tidak beragam. Indeks kemerataan dari keempat lokasi yaitu ladang pertanian, hutan sekunder, tepian sungai, dan hutan primer berkisar 0.650.95 , yang berarti nilai tersebut mendekati 1 yang menunjukkan seluruh jenis memiliki tingkat kemerataan yang sama. Nilai indeks kemerataan spesies yang tinggi menunjukkan bahwa tidak ada satu spesies yang mendominasi spesies lainnya. Sedangkan indeks dominansi dari keempat lokasi penelitian mempunyai tingkat dominansi yang rendah yaitu berkisar antara 0.12-0.31. Hal ini terjadi karena dari keempat lokasi penelitian jumlah indeks dominansi yang ditemukan mendapatkan hasil kurang dari 0.5, yang berarti pada setiap famili di keempat lokasi penelitian individunya tidak ada yang mendominasi karena dominansi komunitas rendah menunjukkan keanekaragamannya sedang sampai tinggi pada keempat lokasi penelitian tersebut. Keanekaragaman, kekayaan, dan kemerataan insekta tanah juga dipengaruhi oleh faktor lingkungan dalam penelitian ini faktor lingkungan yang diukur adalah temperatur tanah, $\mathrm{pH}$ tanah, ketebalan serasah, temperatur udara, kelembaban tanah dan kelembaban udara.

Temperatur tanah adalah salah satu faktor fisika tanah yang sangat menentukan kehadiran dan kepadatan organisme tanah, sehingga suhu tanah akan sangat menentukan tingkat dekomposisi material organik tanah (Suin, 2006). Temperatur tanah pada keempat lokasi berkisar $18^{\circ} \mathrm{C}$ $20^{\circ} \mathrm{C}$. ketebalan serasah sangat berpengaruh dalam keberadaan insekta permukaan tanah karena serasah yang tebal adalah sumber makanan utama bagi insekta tanah, yang dilakukan melalui proses dekomposisi serangga akan mengubahnya menjadi humus dan memanfaatkan serasah untuk berlindung dari predator tanah (Wibowo dan Slvya, 2014).

Tanah di Taman Nasional Gunung Pangrango memiliki $\mathrm{pH}$ sekitar 5.5-6.5 cenderung bersifat sedikit asam. Pada serangga tanah, $\mathrm{pH}$ tanah sangat berpengaruh secara langsung terhadap organ-organ tubuh serangga, maka apabila tanah terlalu masam kelimpahan insekta tanahnya rendah (Ummi, 2007). Menurut Suin (1997), menyatakan bahwa hewan tanah hewan ada yang memilih hidup pada tanah yang pHnya asam dan ada pula senang pada $\mathrm{pH}$ basah. Berdasarkan hasil penelitian $\mathrm{pH}$ yang didapatkan bersifat 
netral yaitu berkisar antara 6.3-7. Temperatur udara di keempat lokasi berkisar antara $18^{\circ} \mathrm{C}-21.2^{\circ} \mathrm{C}$. Kelembaban tanah berkisar 35\%-83\% dan kelembaban udara berkisar $64 \%-70 \%$.

Berdasarkan

perhitungan

menggunakan indeks Morista pola penyebaran yang terjadi antara keempat lokasi diantaranya ladang pertanian, hutan sekunder, tepian sungai, dan hutan primer dari masing-masing plot memiliki pola penyebaran yang berkelompok. Hal ini ditunjukkan dengan perhitungan indeks morista yang dihasilkan yaitu bernilai 10 , yang berarti distribusi yang terjadi pada serangga permukaan tanah di keempat lokasi itu berkelompok. Karena memiliki jumlah nilai indeks morista lebih dari 1 .

\section{KESIMPULAN}

Berdasarkan hasil pengamatan, analisis data, dan pembahasan maka dapat disimpulkan insekta tanah yang teridentifikasi sebanyak 199 individu yang dapat di kelompokan adalah 6 Ordo dan 18 Famili. Ordo yang umum ditemukan adalah Diptera dan Hymenoptera. Indeks kesamaan komunitas berkisar antara 0.140.50 . Keanekaragaman insekta tertinggi dari keempat lokasi berada di daerah hutan primer dengan nilai $\mathrm{H}^{\prime}=2.20, \mathrm{E}=0.95, \mathrm{C}=$ $0.12 \mathrm{R}=3.62$, dan memiliki dominansi terendah yaitu $\mathrm{C}=0.12$. Sedangkan keanekaragaman insekta terendah berada di daerah ladang pertanian $H^{\prime}=1.50, \mathrm{E}=0.65$, $\mathrm{R}=2.14$, dan memiliki dominansi yang tinggi yaitu $\mathrm{C}=0.31$. Pola penyebaran yang dimiliki keempat lokasi adalah pola penyebaran berkelompok.

\section{DAFTAR PUSTAKA}

Borror, Donald J., Charles, A.T., Norman, F. J. 1992. Pengenalan Pelajaran Serangga Edisi Keenam. Yogyakarta : Gadjah Mada University Press.

Indrawan, M., Richard, B.P., dan Jatna, S. 2007. Biologi Konservasi (Rev. ed.). Jakarta: Yayasan Obor Indonesia.
Indriyanto. 2006. Ekologi Hutan. Jakarta: Bumi Aksara.

Odum, E. 1971. Dasar-dasar Ekologi. Yogyakarta: Universitas Gajah Mada Press.

Poth, Hendry. D. 1992. Dasar-dasar Ilmu Tanah Edisi Ketujuh. Yogyakarta : Gadjah Mada University Press.

Suheriyanto, D. 2008. Ekologi Serangga. Malang: UIN-Malang Press.

Ummi, Z.R. 2007. Studi Keanekaragaman Serangga Tanah di UPT Balai Konservasi Tumbuhan Kebun Raya Purwodadi-LIPI. [Skripsi], Malang: Universitas Islam Negeri Malang.

Wibowo, C. dan Sylvia, D.W. 2014. Keanekaragaman Insekta Tanah pada Berbagai Tipe Tegakan di Hutan Pendidikan Gunung Walat dan Hubungannya dengan Peubah Lingkungan. Jurnal Silvikultur Tropika. Vol. 5 (1), $33-4$ 